\title{
PEMBUATAN BAKSO IKAN GABUS DENGAN PEMANFAATAN TEPUNG SAGU YANG MERUPAKAN POTENSI LOKAL SUMBER DAYA ALAM KABUPATEN INDRAGIRI HILIR
}

\author{
Rifni Novitasari ${ }^{*(1)}$ dan Hermiza Mardesci ${ }^{(1)}$ \\ (1) Teknologi Pangan, Fakultas Pertanian Universitas Islam Indragiri, \\ Jl. Propinsi Parit 1 Tembilahan, Riau.29213, Indonesia \\ *rifnivita@gmail.com
}

\begin{abstract}
Abstrak
Telah dilakukan penelitian tentang pembuatan bakso ikan gabus dengan pemanfaatan tepung sagu yang merupakan potensi lokal sumber daya alam Kabupaten Indragiri Hilir pada tanggal dari tanggal 28 September sampai dengan 2 Oktober 2020. Adapun penelitian dilakukan dengan 3 Perlakuan yakni A = Bakso Ikan Gabus dengan penambahan tepung sagu $80 \mathrm{~g}, \mathrm{~B}=$ Bakso Ikan Gabus dengan penambahan tepung sagu $100 \mathrm{~g}$ dan $\mathrm{C}=$ Bakso Ikan Gabus dengan penambahan tepung sagu $120 \mathrm{~g}$, kemudian dari masing perlakuan dilakukan analisa dengan menggunakan metode Uji Hedonik dengan melibatkan 20 orang panelis terlatih. Dari hasil analisa diketahui bahwa perlakuan terbaik adalah perlakuan A dengan skor terhadap warna 7,60, skor rasa 7,45 dan skor aroma 8,35 .
\end{abstract}

Kata Kunci : Ikan gabus, tepung sagu, bakso ikan

\section{PENDAHULUAN}

Indonesia adalah negara yang banyak terdapat tanaman sagu (Metroxylon sagu Rottb) yang tersebar di Papua, Sulawesi, Maluku, Riau dan Kalimantan. Dikutip dari data Kementrian Koordinator Perekonomian, luas sagu di dunia mencapai 6,5 juta hectare (ha). Dari luasan itu, sebanyak 5,43 juta ha atau $83,4 \%$ terdapat di Indonesia (Darmawan, D dan Zuraya, N., 2020)

Tanaman sagu yang banyak tumbuh di wilayah Indonesia, dan kandungan gizinya terutama persentase ketersediaan karbohidrat per $100 \mathrm{~g}$ bahan, membuat sagu sangat potensial untuk dikembangkan sebagai bahan pangan alternative. Menurut Yanica, LA
(2013) cit Heryani dan Silitonga (2017), tanaman sagu dapat digunakan sebagai bahan dasar pembuatan beras analog. Seiring perkembangan teknologi di Indonesia, sagu telah menjadi berbagai olahan pangan yang digemari oleh masyarakat salah satunya adalah penggunaan sagu sebagai bahan baku pembuatan bakso.

Provinsi Riau adalah salah satu pusat potensi lahan tanaman sagu di Indonesia. Sagu dihasilkan di dua kabupaten yakni Kabupaten Indragiri Hilir dan Kabupaten Kepulauan Meranti. (Anonim, 2018).

Sebagai sumber energi, sagu memiliki kandungan protein paling unggul diantara makanan pokok seperti beras, jagung, singkong dan kentang. 
Dibandingkan dengan tepung jagung dan tepung beras, kandungan karbohidrat tepung sagu relatif lebih tinggi yaitu sebesar 381 per 100 gram. Namun demikian, sagu termasuk bahan pangan yang sangat miskin akan protein. Kandungan protein tepung sagu, jauh lebih rendah dari tepung beras, jagung, dan beras. Ditinjau dari kadar vitamin dan mineral, sagu juga memiliki kadar yang lebih rendah dibandingkan dengan bahan makanan pokok lainnya. Menyadari potensi gizi sagu yang tidak selengkap dan sebaik bahan makanan pokok lain, sagu harus dikonsumsi bersama-sama dengan bahan lain yang lebih baik kadar gizinya. Komposisi kimia tepung sagu dapat dilihat pada Tabel 1.

Tabel 1. Komposisi Kimia dalam 100 gam Tepung Sagu (Basis Berat Kering)

\begin{tabular}{|l|c|c|}
\hline \multirow{2}{*}{ Komposisi Kimia } & \multicolumn{2}{c|}{ Sumber } \\
\cline { 2 - 3 } & Rudle, dkk (1978) & Djoefrie (1999) \\
\hline Karbohidrat (\%) & 97,26 & 98,49 \\
\hline Protein & 0,27 & 0,81 \\
\hline Serat kasar (g) & 0,41 & 0,23 \\
\hline Lemak & Sedikit & 0,23 \\
\hline Abu & - & - \\
\hline Kalsium & 0,04 & - \\
\hline Besi & 0,009 & 15,87 \\
\hline Air & 36,99 & 357 \\
\hline Kalori (kkal) & 285 & \\
\hline
\end{tabular}

Disamping kaya akan di bidang pertanian, Kabupaten Indragiri Hilir juga kaya akan hasil laut dan perikanannya. Kabupaten Indragiri Hilir memiliki kondisi geogafis berawa-rawa yang berpotensi untuk menjadi daerah budidaya ikan, khususnya ikan air tawar. Sejak tahun 2017, pemerintah Kabupaten Indragiri Hilir telah mengembangkan budidaya ikan gabus (Channa striata) yang juga dikenal di masyarakat Indragiri Hilir sebagai ikan haruan yang memiliki rasa lezat (Anonim, 2017).

Dirjen Perikanan Budi Daya Kementrian Kelautan dan Perikanan (KKP), Slamet Soebjakto mengingatkan bahwa ikan gabus termasuk komoditas unggulan berbasis lokal sehingga perlu lebih bnyak pelaku usaha yang membudidayakannya (Rahman, MR. 2020).

Lebih lanjut Slamet Soebjakto menguraikan bahwa produksi ikan gabus tahun 2015 mencapai 6.490 ton meningkat di tahun 2019 menjadi 21.987 ton, dengan harga berkisar antara Rp.50 hingga Rp. 80 ribu. Ikan gabus mengandung protein jenis albumin yang berfungsi untuk mengatur tekanan dalam pembuluh darah tidak bocor ke jaringan tubuh sekitarnya.

Menurut Purukan (2013) cit Cahyaningum, D, Agustini, TW dan Romadhon (2015), ikan ini sangat bermanfaat bagi kesehatan karena tingginya kandungan protein albumin yang dibutuhkan untuk perkembangan sel jaringan baru seperti akibat luka, dan sebagainya. 
Menurut Latif, SI (2018), bentuk ikan gabus yang seperti ular kurang banyak disukai oleh masyarakat, padahal di dalam ikan gabus mengandung protein yang sangat tinggi. Ikan gabus sangat kaya akan albumin, jenis protein terbanyak $(60 \%)$ di dalam plasma darah manusia. Peran utama albumin di dalam tubuh sangat penting, yaitu membantu pembentukan jaringan sel baru serta mempercepat penyembuhan pascaoperasi dan melahirkan.

Dalam UU Nomor 18 Tahun 2012 tentang Pangan, disebutkan bahwa penyelenggaraan pangan bertujuan untuk meningkatkan kemampuan memproduksi pangan secara mandiri, menyediakan pangan yang beraneka ragam dan memenuhi persyaratan keamanan, mutu, dan gizi bagi konsumsi masyarakat, mewujudkan tingkat kecukupan pangan, terutama pangan pokok dengan harga yang wajar dan terjangkau sesuai dengan kebutuhan masyarakat. Selain itu juga untuk mempermudah atau meningkatkan akses pangan bagi masyarakat, terutama masyarakat rawan pangan dan gizi, meningkatkan nilai tambah dan daya saing komoditas pangan di pasar dalam negeri dan luar negeri, meningkatkan pengetahuan dan kesadaran masyarakat tentang pangan yang aman, bermutu, dan bergizi bagi konsumsi masyarakat. Tujuan penting lainnya juga meningkatkan kesejahteraan bagi petani, nelayan, pembudidaya ikan, dan pelaku usaha pangan dan melindungi dan mengembangkan kekayaan sumber daya pangan nasional. Dalam konteks demikian, keberlanjutan konsumsi dan produksi sebagai satu kesatuan entitas menjadi sangat penting dalam berbagai tipe ekologi (Ali, et.al, 2017).

Pengolahan pangan berbasis bahan baku lokal mulai digiatkan akhir-akhir ini. Hal ini salah satunya disebabkan sebagai efek pandemi Covid-19 yang berkembang hampir merata di seluruh wilayah Indonesia. Masyarakat harus pandai memodifikasi bahan yang ada untuk menyajikan panganan yang tidak hanya sehat dan bergizi, tetapi juga bahan bakunya gampang diperoleh. Pengolahan panganan berbasis tepung sagu dan ikan gabus secara umum bisa dilakukan seperti membuat olahan berbahan baku tepung terigu dam atau tepung tapioka, yang dikombnasikan dengan ikan seperti bakso, nugget, mpek-mpek dan tekwan.

Bakso secara umum merupakan produk olahan dari daging yang berbentuk bulat kecil dan dapat dimakan secara langsung atau diolah terlebih dahulu. Bakso terbuat dari cincangan daging baik itu daging sapi, daging ayam maupun daging ikan yang diberi campuran bumbu, tepung tapioka, es batu yang kemudian dicampur meratahingga kalis kemudiandibentuk bulatan-bulatan dengan ukuran sesuai selera, kemudian direbus.

Umumnya pembuatan bakso ikan itu dilakukan dengan pencampuran tepung tapioka dengan daging ikan gilinganyang dicampur dengan penambahan bumbu, batu es serpihan. Untuk membuat bakso, diperlukan bahan pengisi atau filler yang biasanya berupa tapioka. Tapioka berpengaruh pada sifat fisik bakso, mengingat tapioka dapat berfungsi sebagai perekat dan mengikat bahan-bahan lain pada adonan bakso (Astawan, 1989). Konstribusi tapioka dalam adonan bakso juga meliputi penambah karbohidrat pada bakso. Karbohidrat tapioka diketahui sebesar 85\% (Gace, 1977). Padahal komponen gizi selain karbohidrat juga diperlukan oleh tubuh. Oleh karena itu, diperlukan bahan alternatif pengganti tapioka yang memiliki komponen gizi lebih baik jika dibanding tapioka. Bahan pengganti 
tapioka bisa diperoleh dari sumber daya lokal di Indonesia yang belum pernah ditambahkan pada produk bakso sebelumnya, yaitu tepung sagu.

Sagu yang dihasilkan di Kabupaten Indragiri Hilir umumnya berupa tepung sagu basah dengan warna abu-abu kecoklatan. Sagu Indragiri Hilir ini biasanya digunakan masyarakat hanya untuk pembuatan kerupuk ebi untuk konsumsi sendiri. Pra-penelitian sebelumnya juga telah dilakukan bahwa sagu lokal ini bisa digunakan sebagai bahan baku pembuatan mpek-mpek dan tekwan dengan pemanfaatan sumber lokal lainnya yakni udang rebon basah.

Jadi pada pembuatan bakso ikan gabus ini, fungsi tepung tapioka disini dalam penelitian ini digantikan dengan pemanfaatan tepung sagu yang merupakan sumber daya alam lokal di Indragiri Hilir. Permasalahannya adalah belum diketahui berapa banyak penggunaan tepung sagu yang digunakan sebagai bahan pencampuran adonan bakso yang tepat sehingga dihasilkan bakso ikan gabus yang disukai secara organoleptik.

Penelitian ini bertujuan untuk mengetahui banyaknya tepung sagu lokal yang tepat yang digunakan sebagai bahan pencampuran adonan bakso sehingga dihasilkan bakso ikan gabus yang disukai secara organoleptik.

\section{METODOLOGI}

\section{Alat dan Bahan}

Bahan baku yang digunakan adalah.ikan gabus, tepung sagu, bawang merah, bawang putih, merica bubuk, garam, gula, telur, baking soda, dan air. Alat yang digunakan adalah sebagai berikut: Pisau tahan karat, talenan, kompor gas, wajan anti lengket, gelas ukur, timbangan, dandang untuk merebus, pengaduk, sendok, ser chopper, piring plating.

\section{Tempat dan Waktu Penelitian}

Penelitian dilakukan dari tanggal 28 September sampai dengan 2 Oktober 2020 yang bertempat di Rumah jalan Wicaksana Blok C No 1 Pekanbaru.

\section{Metode Penelitian}

Peneltian ini dilakukan beberapa tahap, dengan melakukan pra-penelitian tentang banyaknya (g) sagu yang digunakan sebagai bahan pengisi dalam proses pembuatan bakso ikan gabus. Adapun perlakuan penambahan tepung sagu sebagai bahan pengisi pada bakso ikan gabus adalah : A . $80 \mathrm{~g}, \mathrm{~B}-100 \mathrm{~g}$ dan $C=120$ g. Skema pembuatan bakso ikan gabus dapat dilihat pada Gambar 1 . Bakso ikan gabus yang telah masak saat di perebusan ditandai dengan munculnya bakso ikan gabus ke permukaan air perebusan.

\section{Analisa Produk}

Produk bakso ikan gabus yang dihasilkan, akan dilakukan analisa mutu berdasarkan uji organoleptik dengan menggunakan metoda uji hedonik skala 9, yang kemudian dilakukan analisis dengan ANOVA (Analysis of Variance) dan uji lanjut dengan menggunakan metode DNMRT (Duncan's Mutiple Range Test).

Uji hedonik dilakukan dengan menggunakan panelis terlatih sebanyak 20 orang yang telah diseleksi terlebih dahulu. 


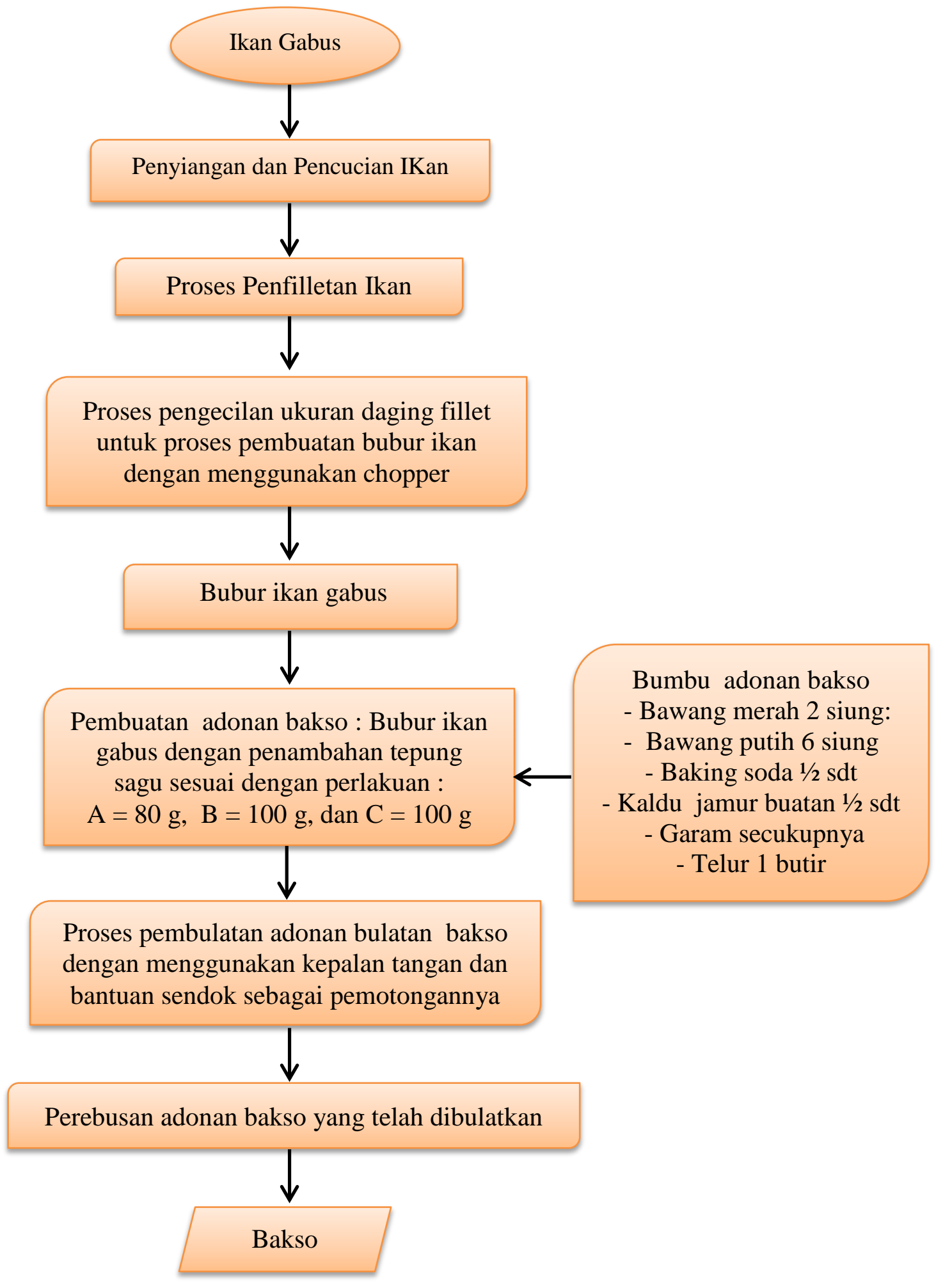

Gambar 1. Diagam Alir Pembuatan Bakso Ikan Gabus 


\section{HASIL DAN PEMBAHASAN}

Uji hedonik atau kesukaan lazim digunakan untuk memilih produk yang lebih diminati/disukai apabila dibandingkan dengan produk lain. Menurut Setyaningsih, D., dkk, uji hedonik ini juga dapat diaplikasikan pada saat pengembangan produk atau perbandingan produk dengan produk pesaing. Berikut hasil uji hedonik dari pembuatan bakso ikan gabus dengan pemanfaatan tepung sagu yang merupakan potensi lokal sumber daya alam Kabupaten Indragiri Hilir.

\section{Warna}

Hasil analisa dengan menggunakan ANOVA dan uji lanjut dengan menggunakan metode DNMRT dapat dilihat pada Tabel 1 .

Tabel 1. Hasil Uji Hedonik terhadap Warna Bakso Ikan

\begin{tabular}{|l|c|}
\hline \multicolumn{1}{|c|}{ Perlakuan } & Rerata Perlakuan \\
\hline A = Bakso Ikan Gabus dengan penambahan tepung sagu 80 g & $7,60 \mathrm{a}$ \\
B = Bakso Ikan Gabus dengan penambahan tepung sagu 100 g & $7.30 \mathrm{~b}$ \\
C = Bakso Ikan Gabus dengan penambahan tepung sagu 120 g & $6.70 \mathrm{~b}$ \\
\hline
\end{tabular}

Ket: Angka-angka yang terletak pada lajur yang sama yang diikuti oleh huruf kecil yang sama berbeda tidak nyata pada taraf 5\% menurut DNMRT

Berdasarkan data dari Tabel 1 diketahui bahwa semakin sedikit pemakaian tepung sagu yang digunakan sebagai bahan pengisi, maka bakso ikan gabus yang dihasilkan semakin bersih/ terang warnanya Sebaliknya, semakin banyak penggunaan tepung sagu, maka bakso ikan gabus yang dihasilkan akan berwarna gelap/keabu-abuan. Hal ini sesuai dengan penuturan Saraswati (1986) cit Utomo, D., Wahyuni, R., Wiyono, R (2011) bahwa warna keabuabuan ini karena adanya reaksi pencoklatan non enzimatis antara asam amino dengan gula reduksi pada suhu pemanasan yang relatif tinggi.

Pernyataan tersebut juga didukung oleh Wijaya, YG (2020) yang menyatakan bahwa bila penggunaan tepung tapioka maka adonan akan berwarna putih bersih, kalau sagu agak keruh warnanya.

\section{Rasa}

Hasil analisa dengan menggunakan ANOVA dan uji lanjut dengan menggunakan metode DNMRT dapat dilihat pada Tabel 2 .

Tabel 2. Hasil Uji Hedonik terhadap Rasa Bakso Ikan

\begin{tabular}{|l|c|}
\hline \multicolumn{1}{|c|}{ Perlakuan } & Rerata Perlakuan \\
\hline B = Bakso Ikan Gabus dengan penambahan tepung sagu $100 \mathrm{~g}$ & $7,80 \mathrm{ab}$ \\
A = Bakso Ikan Gabus dengan penambahan tepung sagu $80 \mathrm{~g}$ & $7.45 \mathrm{bc}$ \\
C = Bakso Ikan Gabus dengan penambahan tepung sagu $120 \mathrm{~g}$ & $7,00 \mathrm{c}$ \\
\hline
\end{tabular}

Ket: Angka-angka yang terletak pada lajur yang sama yang diikuti oleh huruf kecil yang sama berbeda tidak nyata pada taraf $5 \%$ menurut DNMRT 
Berdasarkan data-data yang diperlihatkan pada Tabel 2 diketahui bahwa bakso ikan gabus dengan penambahan tepung sagu $100 \mathrm{~g}$ lebih disukai oleh panelis dengan skor 7,80, sedangkan penambahan tepung sagu $120 \mathrm{~g}$ kurang disukai ditunjukan oleh skor 7,00. Hal ini disebabkan karena semakin banyaknya tepung sagu yang ditambahkan maka tekstur bakso menjadi lebih lengket dibandingkan perlakuan lainnya. Hal ini disebabkan sifat tepung sagu yang lengket. Semakin banyak tepung sagu yang ditambahkan, maka semakin lengket adonan bakso dan semakin lembut, dan empuk. Hal ini sesuai dengan pernyataan Wijaya, YG (2020) yang menyatakan bahwa biasanya tepung sagu digunakan untuk membuat makanan agar memiliki tekstur lembut, empuk dan lengket.
Disamping itu hal ini disebabkan karena perbandingan bubur ikan gabus yang dengan persentase penambahan tepung sagu yang digunakandigunakan dalam proses pengolahan bakso ikan gabus ini mempengaruhi tingkat kegurihan dari bakso ikan yang dihasilkan. Hal ini didukung dengan hasil penelitian Zurkarnain (2014), bahwa perlakuan pembuatan bakso $\mathrm{A}_{1}$ (70\% daging ikan : $30 \%$ tepung tapimal) lebih disukai dibandingkan perlakuan $\mathrm{A}_{2}$ (60\% daging ikan : $40 \%$ tepung tapimal) dan $\mathrm{A}_{3}$ (50\% daging ikan : $50 \%$ tepung tapimal).

\section{Aroma}

Hasil analisa dengan menggunakan ANOVA dan uji lanjut dengan menggunakan metode DNMRT dapat dilihat pada Tabel 3 .

Tabel 3. Hasil Uji Hedonik terhadap Aroma Bakso Ikan

\begin{tabular}{|c|c|}
\hline \multicolumn{1}{|c|}{ Perlakuan } & Rerata Perlakuan \\
\hline $\mathrm{A}$ = Bakso Ikan Gabus dengan penambahan tepung sagu 80 g & $8,35 \mathrm{ab}$ \\
$\mathrm{B}=$ Bakso Ikan Gabus dengan penambahan tepung sagu 100 g & $8,15 \mathrm{~b}$ \\
$\mathrm{C}=$ Bakso Ikan Gabus dengan penambahan tepung sagu 120 g & $6,80 \mathrm{c}$ \\
\hline
\end{tabular}

Ket: Angka-angka yang terletak pada lajur yang sama yang diikuti oleh huruf kecil yang sama berbeda tidak nyata pada taraf 5\% menurut DNMRT

Berdasarkan data dari Tabel 3 diketahui bahwa perlakuan A yakni pembuatan bakso dengan bahan pengisi penambahan tepung sagu sebanyak $80 \mathrm{~g}$ menghasilkan aroma yang lebih disukai oleh panelis dibandingkan perlakuan $\mathrm{B}$ (Penambahan tepung sagu $100 \mathrm{~g}$ ) dan perlakuan $\mathrm{C}$ (Penambahan tepung sagu $120 \mathrm{~g})$. Semakin sedikit penambahan tepung sagu sebagai pengisi bakso ikan gabus, maka aroma ikan gabus pada bakso menjadi lebih kuat, begitu pula sebaliknya. Hal ini dikarenakan persentase penggunaan tepung sagu yang digunakan pada komposisi bubur ikan gabus yang dijadikan adonan pada masing-masing perlakuan adalah sama. Hal ini juga didukung oleh hasil penelitian Zurkarnain (2014), bahwa Perlakuan pembuatan bakso $\mathrm{A}_{1}(70 \%$ daging ikan : $30 \%$ tepung tapimal) lebih disukai dibandingkan perlakuan $\mathrm{A}_{2}(60 \%$ daging ikan : $40 \%$ tepung tapimal) dan $\mathrm{A}_{3}$ (50\% daging ikan : $50 \%$ tepung tapimal).

\section{KESIMPULAN DAN SARAN}

Dari hasil penelitian diketahui bahwa perlakuan A (Bakso Ikan Gabus dengan penambahan tepung sagu $80 \mathrm{~g}$ ) 
adalah perlakuan terbaik dalam pembuatan bakso ikan gabus dengan penambahan tepung sagu sebagai bahan pengisi berdasarkan analisa uji hedonik baik itu dari segi warna, rasa dan aroma yang melibatkan 20 orang panelis terlatih.

\section{DAFTAR PUSTAKA}

Anonim, 2017. HM. Wardan Ingin Mengembangkan Budidaya Ikan Gabus. Riautribune.com tanggal 22 Februari 2017, diakses tanggal 28 Oktober 2020.

Anonim, 2018. Sagu Tak Berduri dari INHIL. Mediaperkebunan. www.mediaperkebunan.id.

Sumber insprirasi agibisnis. 18 April 2018. Diakses tanggal 28 Oktober 2020.

Cahyaningum, D , Agustini, TW dan Romadhon., 2015. Pengaruh Frekwensi Pencucian yang Berbeda Terhadap Kualitas Baksolkan Gabus (Ophiocephalus striatus). Jurnal Pengolahan dan Bioteknologi Hasil Perikanan Volume 4. Nomor 2, Tahun 2015. Hal. 33-39. htpp://www.ejournals1.undip.ac.id//indekx.php/jpbhp

Darmawan, D dan Zuraya, N., 2020. Potensi Besar, 83 Persen Lahan Sagu Dunia Ada di Indonesia, Artikel Republika, Republika co.id, Tanggal 16 Juni 2020, 16.32 WIB diakses 28 Oktober 2020.
Heryani, S dan Silitonga, RF, 2017. Penggunaan Tepung Sagu (Metroxylon sp) sebagai Bahan Baku Kukis Cokelat. Warta IHP? Journal of Ago-based Industry Vol 34 (No.2) 12, $2017: 53$-57

Latif, SI. 2018. Inovasi Bakso dari Ikan Gabus (Channa striata) dengan Subsitusi Daun Kelor (Moringa oleifera) dan Wortel (Daucus carota). Skripsi. Fakultas Teknik Universitas Negeri Makasar.

Rahman, MR., 2020. Ikan Gabus Komoditas Unggulan Berbasis Lokal. Dari lampung.antaranews.com tanggal 27 September 2020, diakses tanggal 28 Oktober 2020.

Utomo, D., Wahyuni, R., Wiyono, R., 2011. Pemanfaatan Ikan Gabus (Ophiocephalus striatus) Menjadi Bakso dalam Rangka Perbaikan Gizi Masyarakat dan Upaya Meningkatkan Nilai Ekonomisnya. Jurnal Ilmiah. Fakultas Pertanian, Universitas Yudharta Pasuruan. Jawa Timur.

Wijaya, YG., 2020. Bedanya Tepung Sagu dan Tepung Tapioka, Kenali Sebelum Bikin Kue. Artikel. Kompas.com Tanggal 30 Juni 2020. Diakses tanggal 29 Oktober 2020.

Zurkarnain, NA., $2014 . \quad$ Studi Pembuatan Bakso Instan dari Ikan Gabus (Ophiocephalus striatus). Skripsi. Progam Studi Ilmu dan Teknologi Pangan, Universitas Hasanuddin, Makasar. 